УДК 655.3.023.6

\title{
ЗАСОБИ ЦИФРОВОГО ВИЗНАЧЕННЯ ТА СТАБІЛІЗАЦІЇ ПАРАЛЕЛЬНОСТІ ПЕРЕДНЬОГО КРАЮ ЛИСТА У ЛИСТОВИХ ДРУКАРСЬКИХ МАШИНАХ
}

( В. Ф. Морфлюк, д.т.н., доцент, НТУУ «КПІ», Київ, Україна

\begin{abstract}
Рассмотрены средства автоматизации процессов измерения и стабилизации параллельности переднего края листа в листовых печатных машинах, обеспечивающие объективность определения параметров в реальном масштабе времени на основе цифровых средств измерения, обработки и стабилизации.
\end{abstract}

Facilities of automation of processes of measuring and stabilization of parallel of cutting edge of sheet in sheet printingpresses are considered, providing objectivity of deter-

mination of parameters in the real time on the basis of digital facilities of measuring, treatment and stabilization.

\section{Постановка проблеми}

Якість друкованої продукції у листових друкарських машинах в значній мірі залежить від точності встановлення паралельності переднього краю листа, що вимагає застосування нових алгоритмів та методів для побудови засобів об'єктивного визначення та регулювання паралельності переднього краю листа.

Визначення та регулювання паралельності переднього краю листа в сучасних умовах будується на методах цифрової обробки результатів вимірювання, які забезпечують підвищення вірогідності та точності визначення паралельності переднього краю листа при розробці засобів автоматизації та дозволяють здійснювати процеси регулювання у реального масштабі часу.

Це визначає один із напрямків забезпечення якості друко- ваної продукції у листових друкарських машинах за рахунок цифрових засобів автоматизації процесів визначення та регулювання паралельності переднього краю листа, що є актуальною проблемою побудови сучасних систем об'єктивного автоматичного регулювання паралельності переднього краю листа.

\section{Аналіз попередніх} досліджень

Тенденції процесів визначення та регулювання паралельності переднього краю листа у листових друкарських машинах показані у роботах [1-4]. У більшості листових друкарських машинах використовується аналоговий принцип регулювання паралельності переднього краю листа, який не дозволяє застосування статистичного способу визначення паралельності переднього краю листа і її стабілізації, що вимагає роз- 
робки алгоритмів та методів цифрової статистичної обробки інформації [5], яка забезпечує вірогідність визначення паралельності переднього краю листа та прогнозоване автоматичне регулювання паралельності переднього краю листа за рахунок об'єктивної оцінки експериментальних вимірів.

\section{Мета дослідження}

Розробка та дослідження цифрових засобів автоматичного визначення та стабілізації паралельності переднього краю листа у листових друкарських машинах.

\section{Результати проведеного дослідження}

На основі аналізу визначено побудову засобів об'єктивного визначення та стабілізації паралельності переднього краю листа у листових друкарських машинах на основі програмно-технічних засобів цифрової стабілізації, які базуються на сучасних перетворювачів аналогової та цифрової інформації (АЦП і ЦАП) та дозволяють підвищити точність результатів вимірювання та стабілізації $( \pm 0,05$ мм та вище), за рахунок використання багаторозрядних АЦП і ЦАП. Застосування сучасних програмних

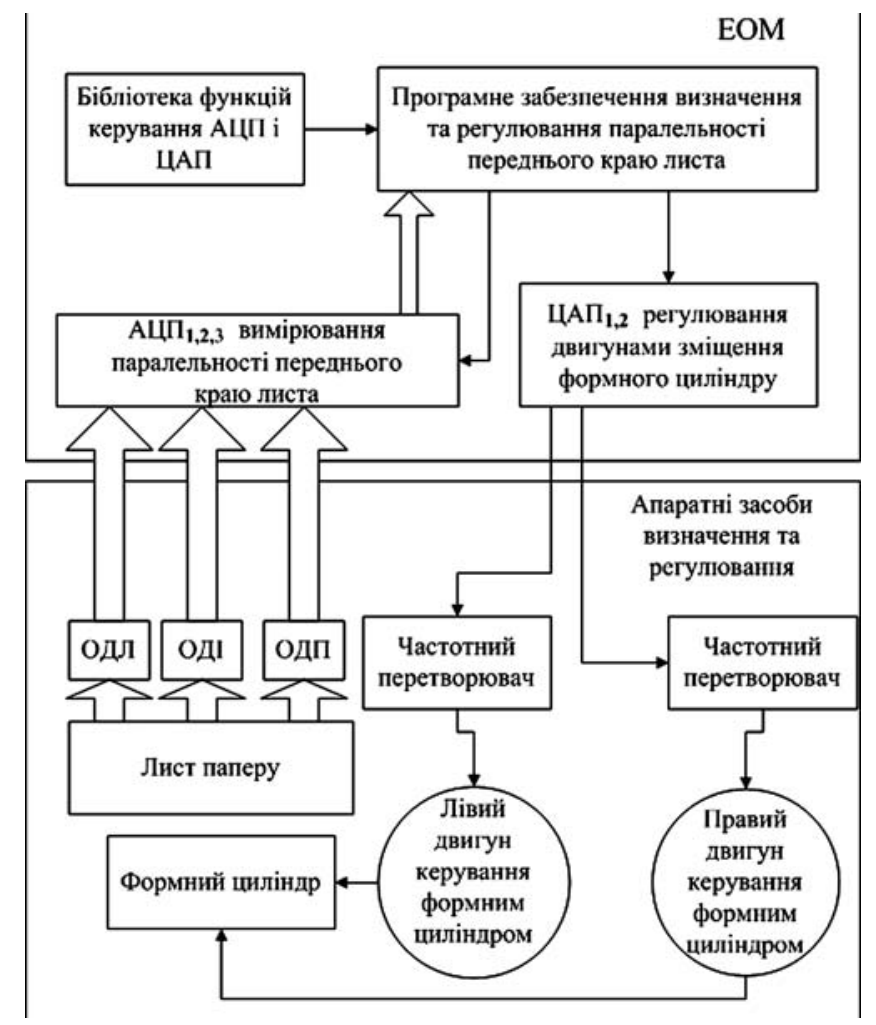

Рис. 1. Структурна схема програмно-апаратних засобів цифрового визначення та стабілізації паралельності переднього краю листа 
засобів на основі статистичної обробки інформації дозволяє забезпечити необхідну достовірність результатів вимірювання, що надає можливість повністю автоматизувати процес вимірювання, обробки та стабілізації паралельності переднього краю листа.

Структурна схема програмно-апаратних засобів цифрового визначення та стабілізації паралельності переднього краю листа рис. 1 складається $з$ аналого-цифрового перетворювачів $\left(А Ц \Pi_{1,2,3}\right)$ для вимірювання параметрів визначення паралельності переднього краю листа, цифро-аналогових перетворювачів (ЦАП1,2) для керування правого та лівого положення формного циліндра з використанням частотних перетворювачів та двигунів зміщення їх положення, EOM з програмним забезпеченням для аналізу значень визначеного положення переднього краю листа і вибору напряму його стабілізації.

Процес автоматичного визначення положення переднього краю листа базується на вико- ристані імпульсних сигналів з оптичних датчиків ОДЛ (оптичний датчик лівий) та ОДП (оптичний датчик правий), встановлених на шляху переміщення технологічних міток відповідних фарб у вигляді прямокутників на листі паперу (рис. 2) та синхронно передають зміну освітлення білої частини паперу та затемненої частини міток і навпаки, яке функціонально відображає параметри відхилення сторін листа від номінального положення, та оптичний датчик ідентифікації листа (ОДІ) рис. 2, 3 для синхронізації запуску аналого-цифрових перетворень у час $\mathrm{t}_{\text {поч}}$.

Імпульсні сигнали рис. 3 за допомогою АЦП та АЦП та під управлінням EOM перетворюються у цифровий код для подальшої обробки, аналізу та прийняття рішення.

Метод цифрового визначення паралельності переднього краю листа базується на порівнянні неузгодженості між парами технологічних міток віддрукованих з правого та лівого боку листа на основі порівняння часу

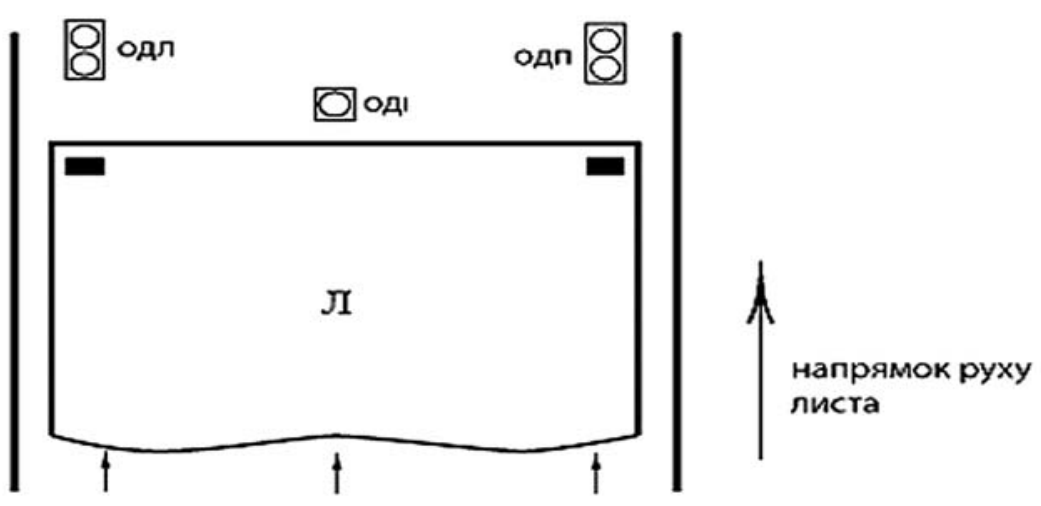

Рис. 2. Розташування оптичних датчиків в листовивідній системі друкарської машини 
$\tau_{\text {імпл }}$ та $\tau_{\text {імпп }}[5,6]$, які моделюють відповідне положення технологічних міток (деякі варіанти рис. 3). Кожна пара технологічних міток являє собою два прямокутника, які розташовуються один за другим і наносяться по черзі $з$ кожним відбитком відповідної фарби та їх зміщення між собою повинно бути в межах $\pm 0,05$ мм.

Необхідність стабілізації положення переднього краю листа визначається наступним чином:

якщо час $\tau_{\text {імпл }}-\tau_{\text {ном }}$ i $\tau_{\text {імпп }}-$ $-\tau_{\text {ном }} \leq\left|\tau_{0,05 \text { мм }}\right|$, то стабілізація не потрібна;

якщо $\tau_{\text {імпл }}-\tau_{\text {ном }}>\tau_{0,05 \text { мм }}$ i $\tau_{\text {імпп }}-\tau_{\text {ном }} \leq\left|\tau_{0,05 \text { мм }}\right|$, то необхідно виконати корегування лівого краю листа; якщо $\tau_{\text {імпп }}-\tau_{\text {ном }}>\tau_{0,05 \text { мм }}$ і $\tau_{\text {імпл }}-\tau_{\text {ном }} \leq\left|\tau_{0,05 \text { мм }}\right|$, то необхідно виконати корегування правого краю листа;

якщо $\tau_{\text {імпл }}-\tau_{\text {ном }}$ i $\tau_{\text {імпп }}-\tau_{\text {ном }}>$ $>\left|\tau_{0,05 \text { мм }}\right|$, то необхідно виконати корегування подачі листів або суміщення фарб.

Процес стабілізації паралельності переднього краю листа залежить від номінального значення $\tau_{\text {імп }}$, яке визначається технічними характеристиками друкарської машини:

$$
\tau_{\text {ном }}=\frac{2 \times \mathrm{L}_{\text {міт }}}{\mathrm{V}_{\text {лист }}},
$$

де $\mathrm{V}_{\text {лист }}-$ швидкість листа паперу; 2 - кількість технологічних міток; $\mathrm{L}_{\text {міт }}$ - ширина технологічної мітки.
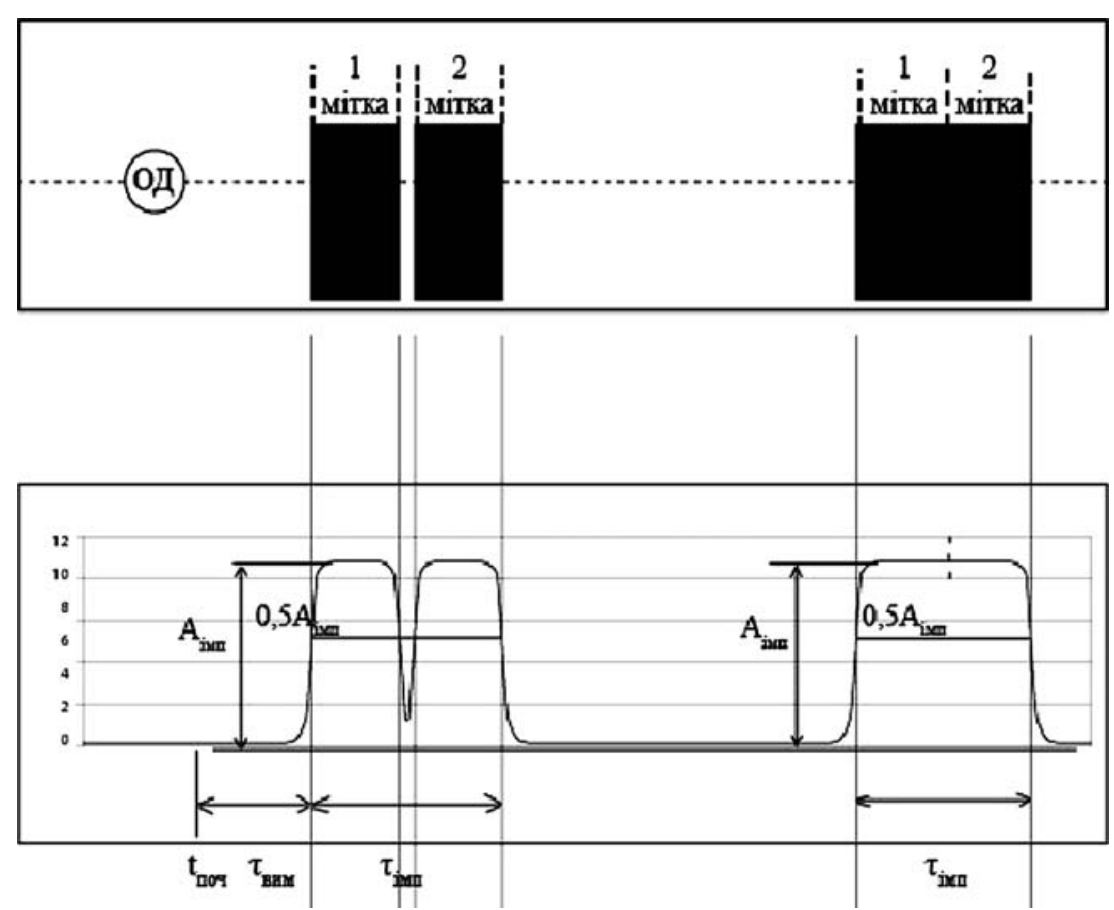

Рис. 3. Лінійна та часова діаграма для обчислення параметрів паралельності переднього краю листа 
Процес визначення паралельності переднього краю листа та встановлення напрямку стабілізації виконуються згідно алгоритму показаного на рис. 4.
Застосування представленого алгоритму та програмно-апаратних засобів цифрового визначення та стабілізації паралельності переднього краю листа до-

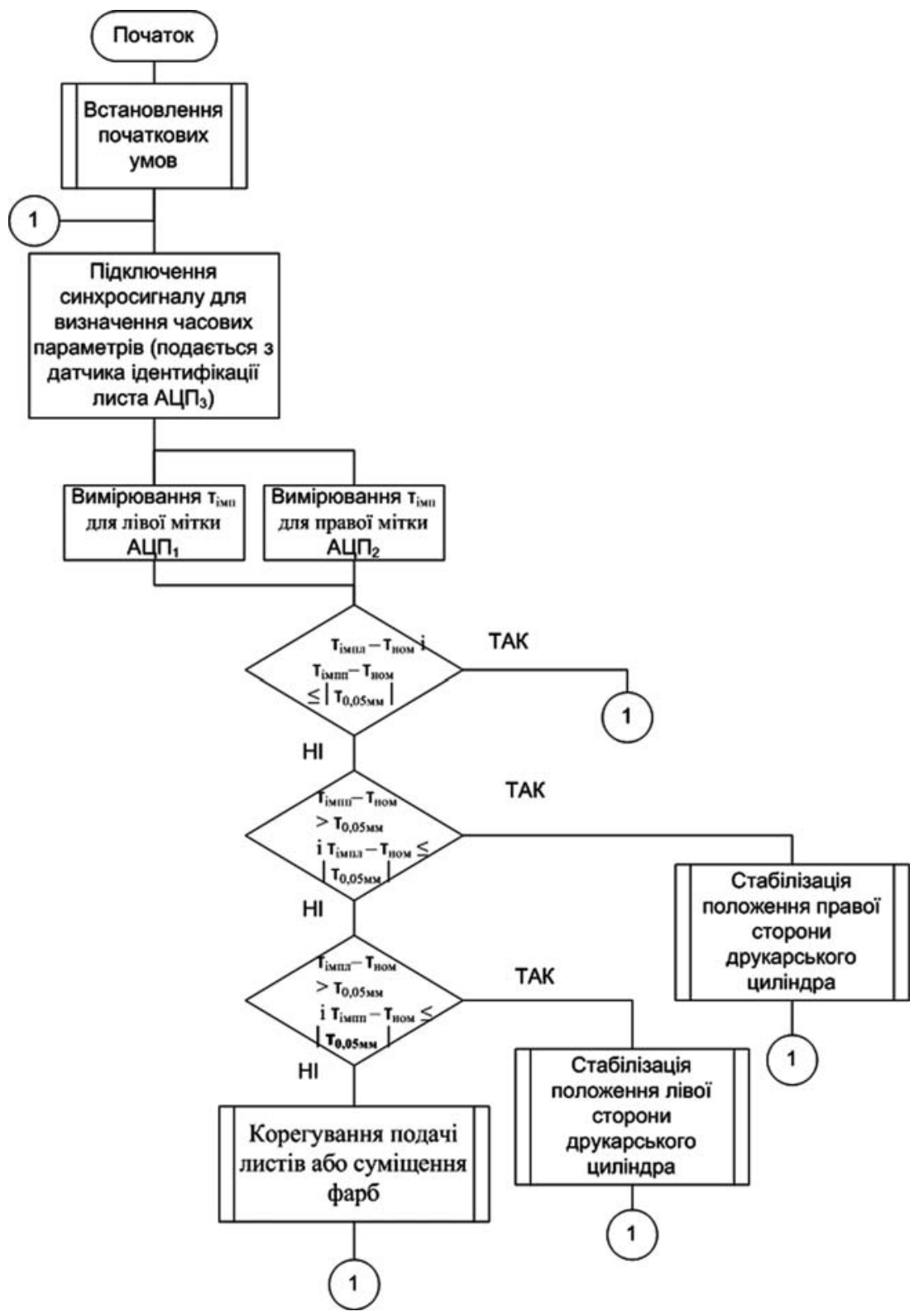

Рис. 4. Алгоритм визначення та стабілізації паралельності переднього краю листа 
зволяють забезпечити об'єктивність та надійність систем автоматичної стабілізації положення переднього краю листа, які повинні будуватися на основі програмних засобів із проблемною орієнтацією, що надає можливість підвищити якість друкованої продукції.

\section{Висновки}

1. Використання засобів цифрового визначення та стабілізації паралельності переднього краю листа забезпечує об'єктивність процесів визначення та регулювання параметрів положення задруковуваного матеріалу в офсетних листових друкарських машинах.
2. Застосування цифрової обробки та аналізу часових параметрів імпульсних сигналів, які моделюють параметри положення листів, на основі програмного керування дозволяє підвищити точність та достовірність визначення паралельності переднього краю листа в офсетних листових друкарських машинах.

3. Застосування цифрових засобів регулювання параметрів паралельності переднього краю листа забезпечує надійність стабілізації положення задруковуваного матеріалу в офсетних листових друкарських машинах.

1. Казакевич В. В. Системы автоматического управления полиграфическими процесами / В. В. Казакевич, Э. И. Избицкий. - М. : Книга, 1978. 341 с. 2. Тюрин А. М. Печатные машины автоматы / А. М. Тюрин. - М. : Книга. - 1980. - 267 с. 3. Heidelberg Druckmaschinen AG, Heidelberg Prinect Signastation, 2006. - 15 с. 4. Полянский Н. Н. Технология полиграфического производства / Н. Н. Полянский. - М., 1991. - 80 с. 5. Морфлюк В. Ф. Цифрове визначення та стабілізація параметрів. технологічних процесів у рулонних друкарських машинах : монографія / В. Ф. Морфлюк. - К. : НТуУ «КП।», 2008. - 164 с. 6. Морфлюк В. Ф. Автоматизація процесів контролю технологічних параметрів поліграфічного устаткування / В. Ф. Морфлюк // Друкарство. - 2001. - № 1. - С. 34-35. 